\title{
Applied solidarity in times of crisis: exploring the contexts of civil society activities in Greece and Germany
}

\author{
Lía Durán Mogollón ${ }^{1} \cdot$ Olga Eisele ${ }^{2} \cdot$ Maria Paschou $^{3}$
}

Published online: 24 March 2020

(c) The Author(s) 2020

\begin{abstract}
The European 'crisis decade' triggered discussions about solidarity and it's limits; at the policy level, the debates were mostly about determining the deservingness of solidarity of each vulnerable group, and at the street level, actors involved saw the demand for concrete service provision grow while their resources stayed the same or retrenched. This paper is interested in the limits of solidarity precisely at the street level; hence we investigate what combinations of operational conditions (budget, status, volunteers) lead the civil society organizations to engage in more solidarity activities (service provision and advocacy). Civil Society Organizations (CSOs) are, beside the state and the family, a vital provider of solidarity services and a significant actor in advocacy for vulnerable groups. As any organization, CSOs are rationalised structures that pursue a concrete goal and for this purpose, rely on different resources and strategies. The paper, therefore, investigates configurations of operational conditions that account for higher levels of solidarity activities by CSOs in Germany and Greece. These countries have both experienced an increase in the demand of social services while they present different civil society traditions, different welfare systems and have been differently affected by crises. While Germany was less dramatically affected by the financial crisis and voluntarily took in almost a million refugees in 2016, Greece was severely hit by the financial crisis and, located at the EU borderland, has had a different experience with the inflow of migrants and refugees. The analysis builds on a series of semi-structured interviews conducted with CSO representatives of the social sector in the framework of the TransSOL project (Www.transsol.eu) in 2017. We employ a fuzzy set qualitative comparative analysis (QCA) to understand the necessary and sufficient conditions under which CSOs are more active, looking at their organizational traits and preconditions, their capacities to mobilise volunteers, their status in the community and their cross-sectional coverage of social issues.
\end{abstract}

Keywords Solidarity · Germany $\cdot$ Greece $\cdot$ Civil Society Organisations (CSOs)

Electronic supplementary material The online version of this article (https://doi.org/10.1057/s4126 9-020-00154-8) contains supplementary material, which is available to authorized users. 


\section{Introduction}

Civil society organizations (CSOs) play a vital role in fostering social cohesion and in implementing solidarity initiatives (Baglioni and Giugni 2014; Maloney and Rossteutscher 2007; Stjerno 2011). They are therefore an integral part of a functioning democracy. As any other organization, CSOs rely on their resources and the institutional structures to survive and accomplish their self-defined mission. In that context, the European crises of the last 10 years have not only triggered intense debates about solidarity (Who is deserving thereof? What are its 'limits'?), but they have, at the street level, increased the demand for concrete implementation of solidarity initiatives in the form of social services and advocacy. In view of this, it is crucial to understand the combination of operational conditions that lead CSOs to engage in more solidarity activities and thus play their part in democratic societies.

Scholars have extensively written about the role and the relevance of civil society in democracies (see: Maloney and Rossteutscher 2007; Stjerno 2011; Davis et al. 2005; Hasenfeld and Gidron 2005). The study of applied solidarity in particular is connected to two strands of social science research: organisational studies and resource mobilisation theory. Given that organised civil society relies, as other organisations, on structures, resources, and environmental constraints, organisational studies provide relevant analytical insights to the study of CSOs. Organisational studies have provided empirical and theoretical accounts of the conditions under which organisations emerge, function and survive (see: Davis et al. 2005; DiMaggio and Powell 1983; Eikenberry and Kluver 2004); analysed how organizations survive and respond to their environment (DiMaggio and Powell 1983) and how they accomplish their goals with the resources available to them (Herman and Renz 2008). Overall, scholars recognise certain conditions which enable CSOs' work and have identified resources that enable them to pursue their goals. The resource mobilisation approach concentrates on the types of resources that SMOs need; financial resources, human resources (personnel, leadership), cultural (know-how) and moral resources (recognition, and status in the community) are among the most salient. The presence and the combinations of such conditions highly determine the kind of work and scope that is feasible for a CSO (see: Edwards and McCarthy 2004; Snow et al. 2008; Kriesi 2007).

In this sense, we are interested in the operational conditions that enable CSOs in Germany and Greece to not only reach out to those in need to meet urgent needs but also to engage in advocacy activities. We aim to explain the configurations of conditions which make it possible for CSOs to implement solidarity initiatives more frequently. Hence, we formulate the following research question: Under what combination of operational conditions do CSOs in Germany and Greece engage in solidarity activities more frequently?

The analysis builds on a series of semi-structured interviews conducted with CSO representatives in the framework of the TransSOL project (www.transsol. eu) in 2017. We employ a fuzzy-set qualitative comparative analysis (QCA) to understand the necessary and sufficient conditions of CSOs' activities looking 
at their organizational traits and preconditions. Eventually, we identify different configurations of conditions lead to the successful implementation of more solidarity measures of CSOs in the two countries. Comparing the two cases allows not only for an assessment of differences but also identifying commonalities. A configurational analysis of the conditions that allow CSOs to engage in more solidarity activities can advance our knowledge about the different ways in which CSOs can adapt to their contexts; respond to demands of their beneficiaries, and also to the availability of resources. Moreover, it also helps to assess in how far the conditions under which these organisations can apply solidarity are similar across countries. And, in that sense, it might also help to assess their potential to grow together in terms of a 'European' civil society (Kröger 2017).

\section{Theoretical framework: civil society organizations and solidarity activities}

Solidarity is understood by social scientists as the willingness to accept some degree of self-sacrifice to assist those in need (Hartwig 2014; Stjerno 2011). It is recognised as an essential trait for a community and, at the same time, its functioning presupposes an accepted imagined community. The implementation of applied solidarity is usually led by different actors; the state, the family and civil society organizations. Given that this study deals specifically with applied solidarity by civil society organisations, the theoretical background is sustained by two strands of research in the social sciences; civil society and organisational studies (e.g., Hasenfeld and Gidron 2005). In the following, we shall briefly discuss both and then highlight how they are connected to our specific research question.

\section{Civil society}

Civil society has been defined in 'attitudinal or institutional' ways (Heidbreder $2012 \mathrm{a}, \mathrm{b})$ as a 'third space' of possible association beyond the state and the market (Diani 2015). Civil society can provide services that citizens might not get from the state or the market, it can serve representative purposes and it can help build citizenship skills (Heidbreder 2012a, b; Baglioni and Giugni 2014). Civil society is considered important for a well-functioning democracy, since it fosters public trust, promotes social capital, stimulates social cohesion and limits state power (Stjerno 2011) and promotes opportunities for advocacy and expression (Hasenfeld and Gidron 2005). Civil society is connected to the state and the economy in different ways, and this can have different shapes in each country. Some civil society groups might have neutral positions towards the state (civil society I; they give the example of self-help groups) others have a defiant position towards the state (civil society II) and some others have cooperative attitudes towards the state (civil society III) (Heidbreder 2012a, b; Hasenfeld and Gidron 2005). The position towards the state, and towards other social actors, might make it easier for CSOs to gain recognition (i.e., 
'moral resources' as described in Edwards and McCarthy 2004) and thus facilitate a relationship of patronage.

\section{Organisational studies}

Organisational studies are relevant for solidarity because sustained solidarity implementation usually occurs through organisational structures; whether it is through state-led institutions, private foundations or civil society organisations. Even the ways in which some long-term social movements mutate and adopt organisational structures in order to endure in time has been documented (Davis et al. 2005). Organizations are defined as goal-oriented entities designed for specific purposes, which have clear tasks and clear boundaries separating them from the environment. To accomplish their goals, organizations rely on different forms of resources and a relationship of credibility with their constituency (Herman and Renz 2008).

Out of these, neo-institutionalism and resource dependency have often proved fruitful explanatory frameworks in the study of civil society organisations, in particular when it comes to the interaction with the environment, the cultural and institutional influences and the adoption of professionalised market practices (Eikenberry and Kluver 2004). While, resource dependency theory is guided by a rational-actor premise that claims that organisations need to make adaptations (and in some case rationalise structures) to obtain the resources they rely on, (Eikenberry and Kluver 2004) neo-institutionalism also considers the field conditions and the recognition.

Resource dependency theory is guided by a rational-actor premise that claims that organisations depend on resources, i.e. financial resources and/or volunteers for their functioning and survival, since these resources are usually found outside the organisations, they would need to make necessary adaptations to access resources. This implies in some cases rationalising structures, adopting professionalised hierarchies and practices from the market (Eikenberry and Kluver 2004).

Neo institutionalism is a further development of Bourdieusian field theory which understands fields as an arena of interaction that includes all actors involved in the production and distribution of specific goods and services. (DiMaggio and Powell 1983). This approach considers that organisations are not simply reliant on resources but also on their ability to gain legitimacy and recognition, and thus secure for themselves the status of a reliable cooperation partner in the community. Moreover, this theoretical perspective also considers that in stable fields, organisations would tend towards isomorphism. In this case, the influences on organisations are not only given by the need for resource but by the institutional and cultural settings in which they are developing.

\section{Resource dependency theory (RDT)}

Resource mobilisation theory argues that SMOs rely on different forms of resources to mobilise and fulfil their goals. RMT mentions financial, moral (recognition, status), cultural (know-how), human (leadership) resources among the most relevant to 
making SMOs function. Moreover, this approach argues that resources, in their various forms are unevenly distributed, and thus organisations find different mechanisms to access them; self-generation, patronage, transfer, etc. As neo-institutionalism, this approach is also influenced by Bourdieusian sociology in that it highlights different forms of capital (resources) and the action and adaptation as not merely rationaloriented but also as frame within a field and within specific cultural practices. This approach and the neo-institutionalist emphasis on recognition, are the fundaments of the conditions we have operationalised for this study.

\section{The forms of organisations in the field of CSOs}

CSOs embeddedness in the specific social, cultural and political context (Font et al. 2007; Cinalli and Giugni 2014) is evidenced by the realignment of the attention scopes and adaptation strategies followed by Greek CSOs since the outbreak of the economic crisis (Skleparis 2015; Clarke et al. 2016). The crisis experience further enriched the variety of CSOs, with new hybrid organizational models emerging beyond formality/informality and legality/illegality divisions, "as social and political actors devise new strategies to actualize social rights that have been suspended" (Simiti 2017, p. 367). Research findings on the scope of activities suggest that despite tensions between the international and the local scopes of action, the everyday practices of cooperation remain tied to the local level (Anheier and Themudo 2002; von Bülow 2010; Baglioni and Giugni 2014). Even the organizations engaged in transnational solidarity remain primarily active at the local or national level (Lahusen et al. 2018). Moreover, the dichotomy between 'professionalized' and 'spontaneous' organizations does not only generate competition for resources but also cooperation between large and small organizations (Kriesi 2007). In addition, advocacy- and service-orientation are usually not mutually exclusive categories but complement each other (Baglioni and Giugni 2014).

This study is specifically concerned with the conditions under which CSOs can engage in more solidarity activities. Here, the literature has identified at least three conditions which relate to resources but also to the organisation's interaction with its environment: Financial resources, membership size, and status in the community (Kriesi 2007; Zmerli and Newton 2007; DiMaggio and Powell 1983; Edwards and McCarhty 2004). In addition, the status in the community is regarded an important indicator, expressed in, for example, the membership of CSOs in public institutions can in the sense of how seriously its work is taken by legislators. How well a CSO is established may also be mirrored in the number of collaborators or its network (e.g., Klüver 2011; Kriesi 2007). In addition, it seems important to look at the salience of the issue on which a CSO works. In this respect, a CSO's capacities to mobilise do not only represent another measure of how established it is in the field but also relates to the public perception of importance of the topic on which CSOs mobilise. Furthermore, some studies looked at networking or activities across boundaries, mainly focusing on social or thematic boundaries, arguing that 'a stronger form of social integration will be achieved by groups crossing boundaries and networking outside their own immediate activity' (Zmerli and Newton 2007, p. 167). Taking 
this argument as a point of departure, a lack of transnational focus of solidarity activities of CSOs could be interpreted also as a lack of social integration of the EU as a political community. In that sense, the aspect of cross-border operation can help to shed light on the capacities of CSOs to grow into some sort of a 'European' civil society. Summing up, then, it seems that the interplay of the operational conditions of budget, status, reliance on volunteers and the scope of activities may serve us well to understand the organisational contexts in which CSOs in Greece and Germany operate and how they hinder or support the success of CSOs in reaching out to those in need.

\section{Methodology}

Following the premises stated in the literature discussed above, it is relevant to briefly introduce the contextual conditions under which CSOs are operating in Germany and Greece. Germany and Greece offer two interesting examples of civil society structure and activity given that both countries were differently affected by the recent European crises and given the different ways in which civil society has developed and functioned in both countries.

\section{Solidarity and civil society in Germany: the social state, labour and Church}

There are 81.4 million people living in Germany (Diehl 2017), making it the largest population in the European Union. Germany is a social state with a contributionbased income distribution system (Kaufmann 2013, p. 208) which follows the principle of subsidiarity in the application and distribution of social services (Kaufmann 2013). Through the delegation of public tasks to non-state actors, the German state incentivizes and builds on the involvement of civil society actors. Hence, it is not surprising that Germany has a relatively well-organised and structured civil society with some visible strong players: the labour movement and the Christian (catholic and protestant) churches (Maloney and Rossteutscher 2007) and also the German sports associations. A lot of CSOs in Germany are in fact members of umbrella organisations such as the Caritas (Catholic Church), Diakonie (Protestant Church), the DGB (the German Association of Trade Unions) and the DOSB (the German Sports Association). These large umbrella organisations have professionalised structures and serve as providers of numerous social services, this is particularly the case of the religious organisations. This means a lot of the organisations receive funding and support from the umbrella organisations, some of which, in turn are (partially) state-funded. Moreover, there is a "vertical integration of the CSOs" (Bovaird et al. 2002). Nonetheless, German civil society is not limited to the labour and church organisations; there are also several smaller, newer CSOs active in the social sector and the number of CSOs has been on the increase (Kriesi 2007).

Germany was differently challenged by the different crises; it proved remarkably resilient to economic downturn during the financial crisis and in 2017 had the lowest unemployment rate in the EU. In contrast, the country experienced the greatest 
intake of refugees of all EU member states, handling around $60 \%$ of all first-time asylum applicants in the EU in 2016. In contrast to the relatively small demand for services resulting for the financial crisis, the arrival of large number of asylum seekers increased the demand for basic services (housing, clothing, legal support, meals), and revived the discussions about neediness, deservingness (who needs help and who deserves solidarity) and about migration and integration. Moreover, this raised the discussions about 'integration and participation': about what it means for people, particularly refugees but also other migrants to be integrated and to what extent are they participating in society (Diehl 2017). This changed panorama drove some of the old and established organisations to set their attention on migration but it also lead to the emergence of some new and smaller organisations that either provided basic services to migrants or engaged in advocacy. Lastly, while German civil society is said to be stable and structured, neo liberal policies and the retrenchment of welfare also affected this sector (Evers and Laville 2004) because it meant some providers of social services, particularly elderly care, are now competing with private providers. Likewise, other CSOs that work as providers of social services (like youth-related services, or counselling) have received contract-based or projectbased contracts which are in some cases restrictive and are short-termed. This 'project-dependency' creates less security but also more pressure to permanently write grants.

\section{Solidarity and civil society in Greece: family, the state and the effervescence resulting from crises}

Greece has a population of 10,770.52 (according to the World Bank Statistics). The Greek welfare system mainly developed as late as in the early 1980s as a "weak form of universalism" and is characterised by a highly fragmented until recently social insurance system and a discretionary and particularistic welfare provision system, traits that are related with weak contractual relations and social citizenship (Petmesidou 1996, pp. 324-325). Unlike Germany, the civil society sector in Greece has been considered as amongst the weakest in Europe with low levels of associational density, volunteerism, social capital and scores of active citizenship (Huliaras 2015; Jones et al. 2015), with the reasons for this being mainly the domination of political parties, clientelism and the predominance of family-based solidarity (Sotiropoulos 2014). Greece is a country where the effects of the financial crisis have been most profoundly felt: in 2012 the unemployment rate was $24.4 \%$ out of which $59 \%$ were long-term unemployed (according to data from the World Bank). The failure of the country to deal with the major dysfunctions of social protection during the previous decades made an overhaul imminent in the period of the crisis but it also put the reform process in dire straits with public social spending being trimmed despite the sharp increase of social needs (Petmesidou and Guillén 2014, p. 297). Likewise, between 2007 and 2016 Greece received 1.374 .800 asylum seekers and migrants, with about a million arriving between 2015 and 2016 (European Stability Initiative 2017, p. 14). These situations pressed the state and the social sector for fast 
and effective responses to the growing needs of both, the indigenous and the migrant population.

While formal civil society remains weak in Greece compared to West European countries, studies of the past two decades have highlighted the development of ad hoc ventures and grassroots initiatives which retain their independence from political party structures, are expressed through contentious forms and direct actions and are organised in informal groups and local solidarity networks (Diani and Kousis 2014; Sotiropoulos 2014; Papadaki and Kalogeraki 2017). Competition over scarce resources prompted NGOs to adopt "adaptation strategies", while the refugee crisis has opened up opportunities in terms of funding and international collaborations (Tzifakis et al. 2017). The rise in funding by private philanthropic foundations has replaced reliance on EU and state funds, without however limiting NGOs dependency on external funding (Tzifakis et al. 2017). The crisis finally boosted civic engagement and voluntarism (Sotiropoulos and Bourikos 2014; Kalogeraki 2018; Tzifakis 2017) due to proximity to suffering as well as the desire of the distressed to benefit from their own active engagement (Clarke 2015).

\section{Data collection}

Turning to the data collection, the analysis is based on a series of 30 semi-structured interviews in each country, Germany and Greece that were conducted in the framework of the TransSOL project. ${ }^{1}$ Regarding the sampling of interview partners, in a first step, CSOs of three different sectors (disabilities, migration, unemployment) were mapped based on systematic google research and relying on information of interview partners in other work packages of TransSOL. Sectors were selected according to considerations of 'deservingness', i.e., as how deserving these groups are perceived by others. ${ }^{2}$ For the organizations mapped, we established a random order in which they were contacted and interviewed until we reached a number of 10 per sector. The questionnaire included open questions as well as single or multiple-choice questions, also pertaining to the organisational traits and the networks of interviewed CSO. For the study at hand, we mainly draw on the standardized part of the questionnaire, thereby explicitly taking the perspective of CSOs in exploring under what organizational conditions they are more active.

In doing so, we do not take different sectors into account in our analysis since the target audiences of some organisations (especially those in the migration and unemployment sector) tend to overlap; some of the interviewed CSOs, especially in Germany, were active in more than one sector, or had overarching target audiences such as 'people in disadvantaged positions'. Overall, the heterogeneity of the sample, including large and small, multi and single issue CSOs makes it ideal to detect more general patterns in the sense of a most diverse case selection. It does, however, also pose some challenges to the researcher in terms of finding common standards or

\footnotetext{
1 Please see transsol.eu for further information; last accessed on 18 March 2020.

2 The project describes this as different 'levels of vulnerability'. The full explanation can be found in the TransSOL Report for Work Package 4, available here: https://transsol.eu/files/2017/12/WP4-Integrated -report-final.pdf; last accessed 18 March 2020.
} 
thresholds to compare them with each other since there is a great probability of outliers. Overall, a number of 50 cases were included in the analysis, excluding some obvious outliers and cases with missing data.

\section{Analysis strategy: fuzzy set QCA}

To analyse our data, we opt for a fuzzy set qualitative comparative analysis (fsQCA; Ragin 1987, 2000, 2008). It is fit for our purposes for the following reasons. First of all, the low number of observations in our sample (50 organizations), which is even reduced by missing values in some variables, does not allow for statistical analysis while it is still rather high when considering in-depth qualitative analysis of individual cases. Moreover, our familiarity and background information about the organisations is 'insufficient' (for a traditional case study approach) but necessary for a configurational analysis (and perhaps more than the necessary for a traditional statistical approach). In this respect, QCA offers a middle path that allows in-depth case analysis along with the possibility to detect broader patterns in the data by determining conditions which are 'necessary' and 'sufficient' for specific social phenomena (Mello 2012). ${ }^{3}$ In addition, 'QCA effectively addresses theoretical hypotheses that predict multiple variables will operate in tandem at specific levels' (Longest and Vaisey 2018, p. 80): Thus, configurations of conditions, i.e., sets, are at the core of this type of analysis.

Set-theoretically grounded methods such as QCA identify combinations of conditions leading to an outcome, based on Boolean logic (Basurto and Speer 2012). QCA is based on the ideas of necessity and sufficiency and it is configurational in approach (Grofman and Schneider 2009, pp. 662/663). Conditions can play different roles in combination with other conditions (multifinality) and that we cannot analyse the occurrence and non-occurrence of an outcome within the same analysis (asymmetric causality). Relating to this, QCA allows for multiple solution sets and thus explicitly includes the notion of equifinality - that there are different possible and empirically observable solutions, i.e., configurations of conditions that lead to an outcome (e.g., Grofman and Schneider 2009, p. 666). This goes well together with what we have discussed earlier about different types of CSOs and their recent developments (e.g., Kriesi 2007).

In addition, our dataset on which we will perform our fsQCA consist of nested data: different CSOs in two countries with very different civil society structures. To account for this, we include country as a condition in the fsQCA. If the country context makes a difference, we shall see the condition in the final solution term. If we do not see it-or only in some paths, then solution paths can account for the outcome independently of the country context (Rohlfing 2012).

\footnotetext{
3 Necessity means that whenever the outcome is present, condition is present, too. When the outcome is not present, the condition may be present still. This, however, does not contradict results. Sufficiency, in contrast, is given whenever the condition is present and the outcome is present, too (Schneider and Wagemann 2012, pp. 329 and 323).
} 
Regarding the calibration of conditions in fsQCA, conditions are continuous and can take any value between 0 and 1 (Pennings 2009). Different levels represent different degrees of membership in a condition, which allows for fine-grained analyses in which, however, turnover points or degrees of membership have to be carefully defined (e.g., Cacciatore et al. 2015; Grofman and Schneider 2009; Mello 2012; Schneider and Wagemann 2006, 2009). Moreover, fsQCA can easily become dysfunctional by overloading the analysis with too many conditions. We therefore follow the common practice to reduce conditions and aggregate them into more complex, higher constructs (Schneider and Wagemann 2009; see also Cacciatore et al. 2015). The variables used for conducting our fsQCA were taken or computed from several variables contained in the TransSOL questionnaire and analysed using the 'fuzzy' package in Stata (Longest and Vaisey 2018) as well as Tosmana (Cronqvist 2016).

We will first look at the operationalisation of the outcome: As discussed earlier, we look at the frequency of CSOs direct solidarity activities as the outcome. Thus, we look at CSOs' activities in which CSOs are directly in contact with their actual target group. This excludes 'indirect' activities like interest representation in institutions, for example. Against the background of fsQCA as our method of analysis, we are here interested in configurations leading to the outcome; so we will not analyse the non-occurrence of the outcome in this study.

Two aspects are distinguished along which questions were organised in the questionnaire. First, activities of CSOs can pursue more charity-oriented goals such as immediate help regarding, e.g., food or medication. Second, activities can seek to raise awareness about specific problems and may then be rooted in political activism aimed at changing legislation, for example (Baglioni and Giugni 2014). Accordingly, the questionnaire probed (1) the provision of services, e.g., support regarding housing, access to welfare state services, financial or in-kind support or legal assistance; and (2) the organisation of events, i.e., intellectual debates, excursions, political discussion rounds, sportive competitions or seminars on the implementation of public programs. In all these variables, interviewees were asked for the frequency of provision/organisation ranging from 0 to 2 (services) or 0 to 3 (events)-once for the national context, and once for cross-border activities (transnational). After first descriptive analyses, we found that transnational activities were extremely rarely reported at all, which is we decided to add national and transnational activities and analyse the influence of the operating level by including a distinct variable included in the questionnaire (see below). Thus, activities for both levels were merged for the outcome variable. In the next step, all service variables and event variables were added and averaged within the respective category (e.g., all nine service variables added up and averaged). Both resulting variables, i.e., one for services and one for events, were then added to form an additive index of solidarity activities, here looked at as direct outreach to those in need. Finally, rather than analysing different types of engagement separately, we opted for including both types in the same QCA, also against the background that most CSOs are in fact involved in both. The outcome, thus, is included as a count variable of activities at national and transnational level, as well as services and events.

We now turn to discussing the operationalisation of individual conditions. Based on the theoretical considerations discussed above, we include the following 


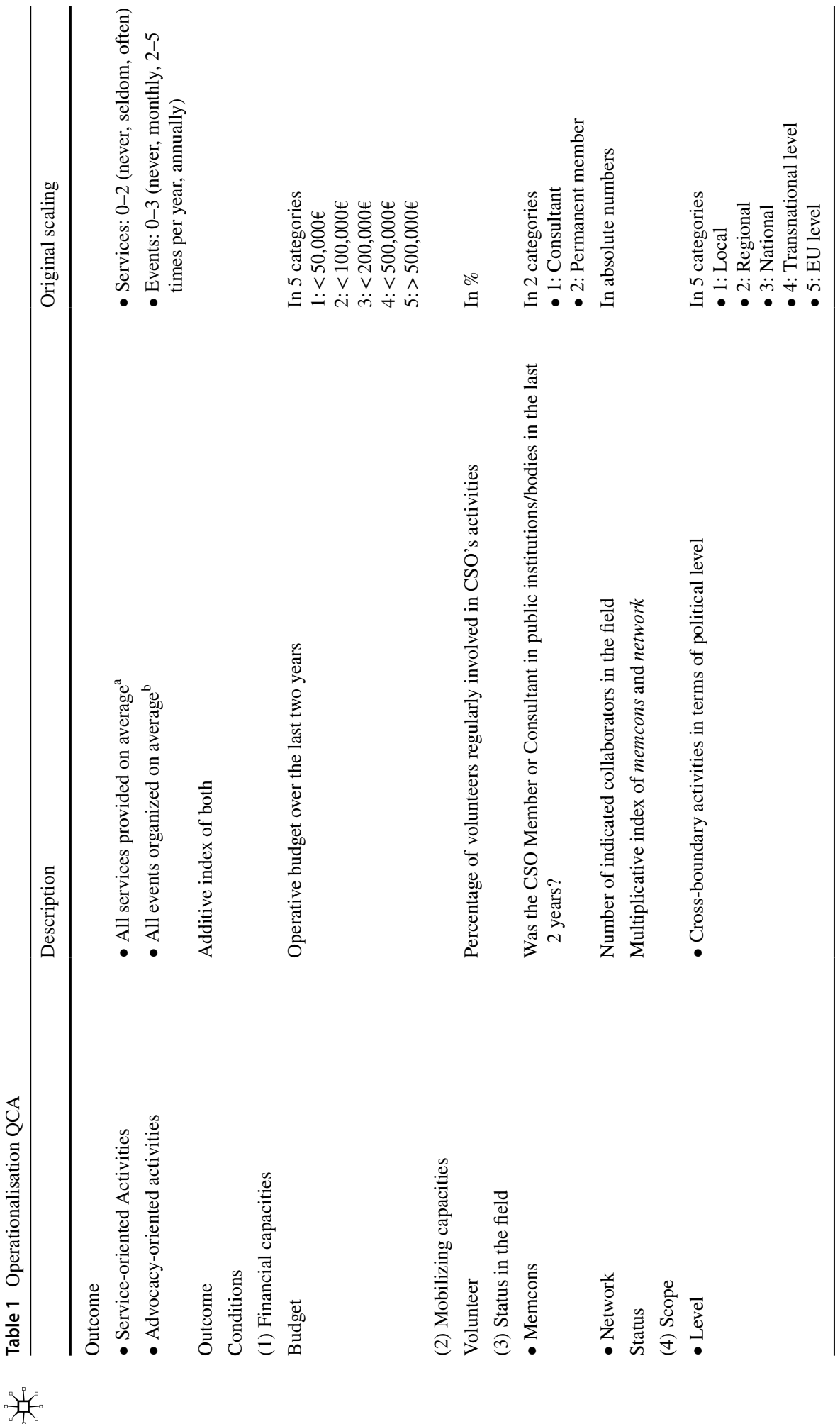




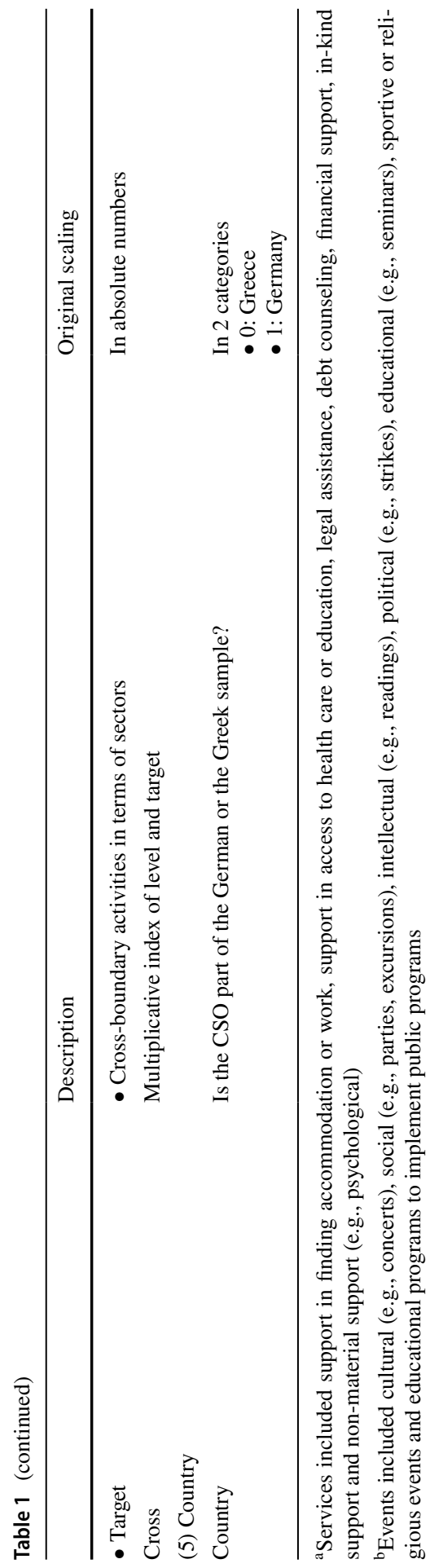


categories in our fsQCA analysis: (1) financial capacities; (2) the capacities of the CSO to mobilize; (3) the status in the field; and (4) the scope of the CSO as regards its cross-boundaries operations and the target group. All of these variables were included in the standardized questionnaire in the form of single or multiple-choice questions (see Table 1; see Supplementary Material C for a discussion of how conditions were translated into fuzzy sets).

For the category of (1) financial capacities, interviewees were asked to indicate their operating budget selecting from five different categories. As an indicator for (2) the mobilising capacities of the $\mathrm{CSO}$, we included a question regarding the percentage of volunteers that is regularly involved in activities organised or offered by the CSO. For both conditions, the measurement is very straight forward and not modified.

The (3) embeddedness or establishment in the field is measured by a proxy, on the basis of two indicators probing the density of CSOs networks. First, we include the question if the CSO is a consultant or member of public institutions. Based on the underlying assumption that an organisation is more established if it is a permanent member, and thus is entrusted with playing a more important role in policymaking, being a permanent member is assigned a higher score than being a consultant; this variable was averaged from three variables that were targeting this question at the EU, national, and subnational level. In addition, we include the self-reported number of collaborators in terms of project work relying on the earlier described map of relevant CSOs in the field, while allowing for entering organizations missing from the provided list, too. These two measurements are then multiplied to form an index of the establishment in the field.

The (4) scope of CSOs' work is included looking at aspects of 'crossing borders'. First, the transnational aspect of solidarity work is considered by including the question at which level the CSO operates. This was probed for different types of activities; however, we only use the highest level indicated for defining the membership score. In addition, respondents were asked to indicate their activities per sector $(0-2$ scale). Adding these activities across sectors, we averaged obtained values, resulting in a score for intersectional activities to define the scope of CSOs' work in terms of their cross-sectional coverage. Assuming that both variables interact-i.e., the scope of a CSO's work increases exponentially when both conditions are met, both variables were then multiplied to obtain an index for the scope of the CSO.

Finally, (5) country is inserted in the fsQCA as an additional condition to account for differences between the German and the Greek case.

\section{Results}

Before starting to discuss the results and checks for the fsQCA, we provide some figures to gain a broader understanding of the data we analyse. ${ }^{4}$ This is also helpful for understanding the translation of variables into fuzzy sets (see Supplementary

\footnotetext{
${ }^{4}$ CSOs' representatives were ensured anonymity which is why we will resort to describing CSOs' characteristics without identifying them explicitly in the discussion of results.
} 


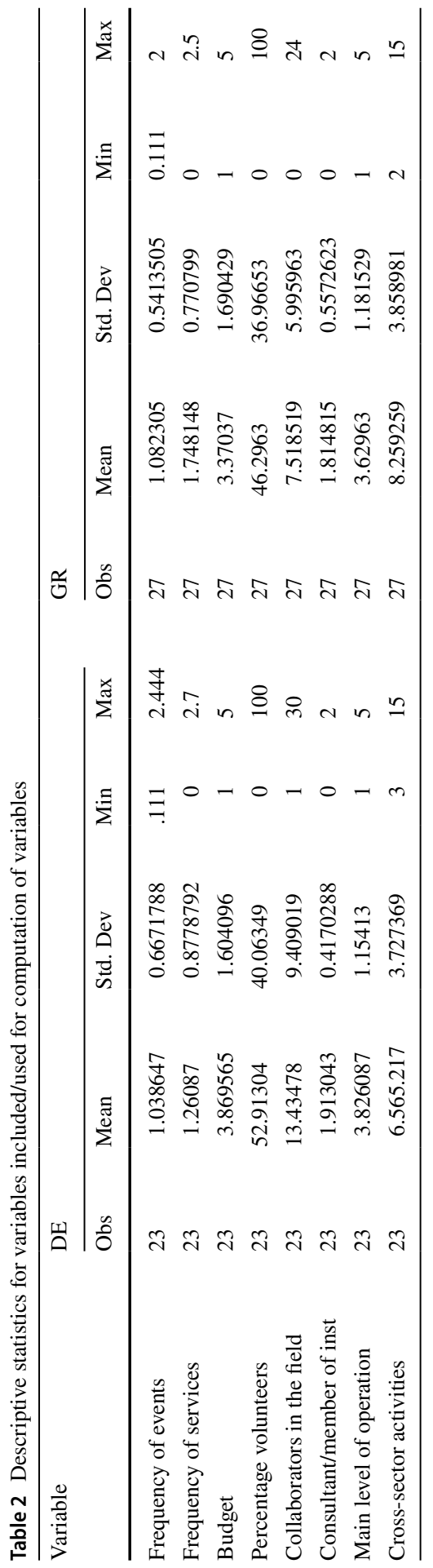


Table 3 Two final solution terms (intermediate solution)

\begin{tabular}{lll}
\hline & Consistency & Coverage \\
\hline Solution Term 1 & & \\
BUDGET * STATUS * scope + & 0.8597 & 0.4946 \\
BUDGET * VOLUNTEER * STATUS + & $\mathbf{0 . 8 8 4 8}$ & $\mathbf{0 . 3 8 7 5}$ \\
BUDGET * scope * country + & 0.8578 & 0.3377 \\
STATUS * scope * country + & 0.8386 & 0.2746 \\
volunteer * STATUS * country + & 0.8841 & 0.3901 \\
BUDGET * VOLUNTEER * SCOPE * COUNTRY & 0.9301 & 0.219 \\
Solution consistency & & 0.8340 \\
Overall coverage & & 0.8923 \\
Solution Term 2 & & \\
BUDGET * STATUS * scope + & 0.8597 & 0.4946 \\
BUDGET * STATUS * country + & $\mathbf{0 . 8 3 0 5}$ & $\mathbf{0 . 3 7 4 8}$ \\
BUDGET * scope * country + & 0.8578 & 0.3377 \\
STATUS * scope * country + & 0.8386 & 0.2746 \\
volunteer * STATUS * country + & 0.8841 & 0.3901 \\
BUDGET * VOLUNTEER * SCOPE * COUNTRY & 0.9301 & 0.219 \\
Solution consistency & & 0.8307 \\
Overall coverage & & 0.8813 \\
\hline
\end{tabular}

*Logical AND, +logical OR

Material $\mathrm{C}$ for a detailed discussion of where we set turnover points in the translation into fuzzy sets) (Table 2).

Events seem to be less frequent activities than services, which mirrors the foci of included CSOs in both countries. The percentage of volunteers seems quite high as is the standard deviation here, indicating large differences between CSOs. The budget variable displays a rather high budget with an even higher average in Germany; German CSOs also report a higher number of collaborators and seem to be consultants or members of institutions more often. Greek CSOs, then, report a higher level of cross-sectoral activities.

A number of checks were conducted for our fsQCA analysis following the standards of good practice set out by Schneider and Wagemann (2012; see Supplementary Material A). Those resulted in the finding that there is no necessary condition for the outcome to occur across countries-yet for the German case, a higher budget came very close. After taking care of logical remainders (non-observed, but logically possible configurations), we reduced possible configurations to two solution terms which fit the data equally well, indicating some degree of ambiguity in our fsQCA (see Table 3; set marked in bold). 
The main configuration of conditions leading to the outcome of more frequent activities is the solution set BUDGET * STATUS * scope, which appears in both terms with the highest coverage indicating a higher relevance of this configuration; given that the country condition does not play a role here, we conclude that, independent of the country in which our CSOs operate, they are more active when they have a higher budget and higher status (i.e., a denser network) and when the scope of their activities is smaller, i.e. they operate at a lower level and/or on more narrowly defined issues.

Interestingly, there seem to be considerable differences between the two samples given the appearance of the country condition in many of the solution sets. The Greek sample seems to offer more variance: Greek CSOs can either have a higher budget in combination with a more focused scope of activities, or a higher status combined with either a lower scope or a lower reliance on volunteers. For the German case, CSOs with a higher budget (a necessary condition for the German case), high reliance on volunteers and a broad focus of activities report more activities.

Looking at the solutions which distinguish the two solution terms (marked in bold in Table 3), we may either see more active CSOs when they have a high budget, high reliance on volunteers and a denser network, or we may see a positive outcome for Greek CSOs when they have a high budget and dense network. Given the ambiguity of these two solution terms, however, we will here focus on the sets that are congruent in both terms (see Supplementary Material B for $X Y$ plots of each solution set).

\section{Discussion, conclusions, and avenues for future research}

One of the most salient results is that, regardless of national context, the configuration which most frequently leads to an outcome is budget, status and a reduced geographical scope. This resonates with some of the explanations provided by the interview partners who often stressed that operating beyond a local level demands higher resources (monetary but also contacts and time) and that sometimes the 'limits of solidarity' are set by the limits of these resources or by the scope of action that an organization has set for itself. The importance of a greater scope of activities for achieving the outcome, then, may be seen as a mirror of the fact that we included some rather large players, such as trade unions, for example, that tend to work crosssectionally and are usually better connected to counterparts beyond national borders.

Furthermore, this configuration, and the fact that budget and status appeared to be present on most configurations that lead to the outcome, goes in line with what has been suggested by the non-profit literature: these organisations rely on material resources and a "relationship of credibility" with the public and the context. This configuration suggests a certain degree of organizational formalization among those cases where the outcome was achieved; a high and steady budget combined with dense networks of collaboration and membership/ consultancy status suggest a well-established and highly professionalized organizational profile. This resonates with some of the premises of resource dependency and neo-institutionalism; the necessity of securing resources, the tendency towards formalisation and rationalisation and the importance of gaining legitimacy in the field. Moreover, a reduced 
geographical scope might make it easier to use resources more efficiently and to maintain networks.

In terms of national differences, the fact that more combinations lead to an outcome in Greece than in Germany suggests an adaptation to a more dynamic and unstable environment: future research could concentrate on how the cuts created by the financial crisis and the traditionally low levels of volunteerism in Greece might have triggered the development of specific organizational forms in the civic sector.

In addition, it is worth mentioning that budget was a necessary condition in the German sample but not for the Greek. This might also be suggesting more formalization and professionalization in the German case which relies more strongly on steady funding. The extent to which this might be a response to the institutional settings and the relationship of subsidiarity (wherein providers of services compete with one another for contracts with the state for the provision of social services) with the state is certainly an interesting question for future inquiry; most of the German CSOs surveyed were heavily dependent on state funds $(51.7 \%$ of them said grants from national governments are "very relevant" for their finances and $6.9 \%$ said they were fairly relevant). The second-most important source of funding for the German sample were contributions from members: $44.8 \%$ described this source of funding as 'highly relevant' and $20.7 \%$ as fairly relevant.

This suggest that civil societies which are very structured and professionalised, budget becomes a necessary condition for operating and engaging in solidarity, whereas, this is not the case for more volatile civil societies, with less bonds of cooperation with the state. This reminds us of one of the core arguments of RMT; that some resources are context-relevant (which is not to say that financial resources are irrelevant in any context, but rather that the importance of larger and regular budgets are context-dependent). This also highlights that legitimacy and recognition are particularly relevant when it comes to civil society actors. The salience of budget as a necessary condition in Germany and the strong reliance on state funding also raise questions about the 'openness' of the field: does this still foster and allow for the rise of bottom up initiatives in terms of the allocation of solidarity but also in terms of the initiatives that are needed? To what extent does it mean that the state is 'setting the agenda' in terms of the recipients of solidarity and the types of initiatives covered (whether these are direct services or rather more long-term programmes)?

For the Greek case, in contrast, over $40 \%$ of included CSOs report a severe retrenchment in funding or available resources, with over $60 \%$ stating that financial resources provided by the national government are completely irrelevant. Interestingly, 20\% of CSOs reported EU grants to be the most relevant source of financial resources which are amongst the most irrelevant in Germany. In addition, the importance of status, i.e., a well-established network, seems much more important in Greece. Crises indeed increased the necessity to find different ways to achieve the desired results and to compensate for the retrenchment in welfare programs caused by austerity policies.

The fact that a reduced scope was more frequently present on the configurations that lead to the outcome goes in line with much of what the CSO literature suggests: that solidarity is still local. An interesting question for future research could be whether this applies exclusively to those forms of regular and structured forms 
of applied solidarity as the ones carried out by established organizations or whether this applies (to some given extent) to more spontaneous and ad hoc actions as well. Lastly, it would be interesting to explore the extent to which this local bias is a response to the institutional settings and the material constraints of cross-border solidarity or whether it mostly relates to national frames and experiences with the European crises. In this respect, it is important to mention one significant difference: transnational scope only leads to more frequent activities in Germany and when all other conditions show a high presence (i.e., high budget, great number of volunteers). This could suggest that the more professionalized and formalized organizational forms are, the more capable they are of maintaining transnational ties and fully benefiting from them. This is mirrored also in the information gathered through the qualitative interviews in which organizational representatives stressed the logistical costs of transnational operations.

The status, a variable in this case was composed of the number of connections and collaborators, and regarding whether or not they are consulted by state organs. The fact that this condition is not that important in Germany but more so in Greece suggests that this kind of solidarity between civil society actors can be more important in contexts in which the reliance on the state is reduced (whether this happens such as in Greece, where the finance crisis led to severe welfare cuts and reduced government spending or in other ways) From this, an interesting question for further research could be to assess if this would also happen in cases of CSOs that are deliberately trying to be less dependent on the state. Or rather, would this be the case for CSOs that have a less reliable or reduced budget?

Overall, national differences resonate with the neo-institutionalist premise that claims that in stable conditions, organisations will tend towards professionalization and rationalisation, which is expressed by the German case. Volatile and unstable conditions can lead organisations to be reactive and more flexible, which was visible in the Greek case. Some national differences also stress the importance of institutional, political and cultural settings in organisational development and shows that organised civil society is still bound by the institutional, cultural and political settings at the national level.

Acknowledgements Open access funding provided by University of Vienna. The authors would like to thank Simone Baglioni, Maria Kousis and Christian Lahusen, as well as the anonymous reviewers, for helpful comments on earlier versions of this article. This study was conducted in the framework of the TransSOL project. TransSOL was funded under the European Commission's Horizon2020 programme (Grant No. 649435). See www.transsol.eu for further details.

\section{Compliance with ethical standards}

Conflict of interest The Authors report no conflict of interest for this submission.

Open Access This article is licensed under a Creative Commons Attribution 4.0 International License, which permits use, sharing, adaptation, distribution and reproduction in any medium or format, as long as you give appropriate credit to the original author(s) and the source, provide a link to the Creative Commons licence, and indicate if changes were made. The images or other third party material in this article are included in the article's Creative Commons licence, unless indicated otherwise in a credit line to the material. If material is not included in the article's Creative Commons licence and your intended use is 
not permitted by statutory regulation or exceeds the permitted use, you will need to obtain permission directly from the copyright holder. To view a copy of this licence, visit http://creativecommons.org/licen ses/by/4.0/.

\section{References}

Anheier, H.K., and N. Themudo. 2005. The internationalization of the nonprofit sector. In The JosseyBass handbook of nonprofit leadership and management, 102-127. Hoboken: Wiley.

Baglioni, S., and M. Giugni (eds.). 2014. Civil society organization, unemployment, and precarity in Europe. Organizational Activities and Networks. Houndmills, Basingstoke, Hampshire, England; New York: Palgrave Macmillan.

Bast, J. 2014. Solidarität im europäischen Einwanderungs-und Asylrecht. In Solidarität in der EU, 143162. Baden: Nomos Verlagsgesellschaft Baden.

Barman, E. 2016. Varieties of field theory and the sociology of the non-profit sector. Sociology Compass 10 (6): 442-458.

Basurto, X., and J. Speer. 2012. Structuring the calibration of qualitative data as sets for qualitative comparative analysis (QCA). Field Methods 24 (2): 155-174.

Bovaird, T., E. Löffler, and S. Parrado-Díez. 2002. Finding a bowling partner: The role of stakeholders in activating civil society in Germany, Spain and the United Kingdom. Public Management Review 4 (3): 411-431.

Cacciatore, F., A. Natalini, and C. Wagemann. 2015. Clustered Europeanization and national reform programmes: A qualitative comparative analysis. Journal of European Public Policy 22 (8): $1186-1211$.

Cinalli, M., and M. Giugni. 2014. The impact of political opportunity structures on the politicization of civil society organizations in the field of unemployment and precarity. In Civil society organizations, unemployment and precarity in Europe, ed. S. Baglioni and M. Giugni. Palgrave-MacMillan: Basingstoke.

Clarke, J.A. 2015. Solidarity and survival: A multidisciplinary exploration of volunteering during the Greek crisis. In Austerity and the third sector: Civil society at the European frontline, ed. J. Clarke, A. Huliaras, and D.A. Sotiropoulos. London: Routledge.

Clarke, J., A. Huliaras, and D.A. Sotiropoulos. 2015. Introduction. In Austerity and the third sector: Civil society at the European frontline, ed. J. Clarke, A. Huliaras, and D.A. Sotiropoulos. London: Routledge.

Cronqvist, L. 2016. Tosmana [Version 1.521]. University of Trier. Internet: http://www.tosmana.net.

Davis, G.F., D. McAdam, W.R. Scott, and M.N. Zald (eds.). 2005. Social movements and organization theory. Cambridge: Cambridge University Press.

Diani, M. 2015. The cement of civil society. Cambridge University Press.

Diani, M., and M. Kousis. 2014. The duality of claims and events: The Greek campaign against the Troika's Memoranda and austerity, 2010-2012. Mobilization 19 (4): 387-404.

Diehl, E. 2017. Teilhabe für alle? Lebensrealitäten zwischen Diskriminierung und Partizipation. Bonn: Bundeszentrale für politische Bildung.

Clarke, J., A. Huliaras, and D.A. Sotiropoulos. 2016. Crisis and civil society in Greece. The European Financial Review Oct-Nov: 28-30.

DiMaggio, P.J., and W.W. Powell. 1983. The iron cage revisited: Institutional isomorphism and collective rationality in organizational fields. American Sociological Review 48: 147-160.

Dotti Sani, G., and B. Magistro. 2016. Increasingly unequal? The economic crisis, social inequalities and trust in the European Parliament in 20 European countries. European Journal of Political Research 55: 246-264.

Durkheim, E. 2014. The division of labour in society. New York: Simon and Schuster.

Eder, K., and M. Kousis (eds.). 2001. Environmental politics in southern Europe: Actors, institutions and discourses in a Europeanizing society. Dordrecht: Kluwer Academic Publishers.

Edwards, B., and J.D. McCarthy. 2004. Resources and social movement mobilization. In The Blackwell companion to social movements, ed. D.A. Snow, S.A. Soule, and H. Kriesi, 116-152. Oxford: Blackwell. 
Eikenberry, A.M., and J.D. Kluver. 2004. The marketization of the nonprofit sector: Civil society at risk? Public Administration Review 64 (2): 132-140.

European Stability Initiative. 2017. The refugee crisis through statistics. Berlin: ESI.

Evers, A., and J.L. Laville (eds.). 2004. The third sector in Europe. Cheltenham: Edward Elgar Publishing.

Font, J., P. Geurts, W.A. Maloney, and M. Berton. 2007. Organizations in context: Politics hand culture shaping associational life. In Social capital and associations in European democracies, ed. W. Maloney and S. Rossteutcher. London: Routledge.

Giugni, M., and S. Baglioni. 2014. Civil society, unemployment, and precarity in Europe: A conclusion. In Civil society organizations, unemployment, and precarity in Europe: Between service and policy, ed. S. Baglioni and M. Giugni. Palgrave-MacMillan: Basingstoke.

Grofman, B., and C.Q. Schneider. 2009. An introduction to crisp set QCA, with a comparison to binary logistic regression. Political Research Quarterly 62 (4): 662-672.

Hartwig, I. 2014. Solidarische Kohäsionspolitik jenseits 2013. In Solidarität in der EU, 163-192. Baden: Nomos Verlagsgesellschaft mbH \& Co. KG.

Hasenfeld, Y., and B. Gidron. 2005. Understanding multi-purpose hybrid voluntary organizations: The contributions of theories on civil society, social movements and non-profit organizations. Journal of Civil Society 1 (2): 97-112.

Heidbreder, E. 2012a. Civil society participation in EU governance. Living Reviews in European Governance 7(2). https://www.livingreviews.org/lreg-2012-2. Cited 10.12.2019.

Heidbreder, E.G. 2012b. Civil society participation in EU governance. Living Reviews in European Governance 7(2). https://www.livingreviews.org/lreg-2012-2.

Herman, R.D., and D.O. Renz. 2008. Advancing nonprofit organizational effectiveness research and theory: Nine theses. Nonprofit Management and Leadership 18 (4): 399-415.

Huliaras, A. 2014. The dynamics of civil society in Greece: creating civic engagement from the top. The Jean Monnet Papers on Political Economy.

Huliaras, A. 2015. Greek civil society: The neglected causes of weakness. In Austerity and the third sector: Civil society at the European frontline, ed. J. Clarke, A. Huliaras, and D.A. Sotiropoulos. London: Routledge.

Jones, N., M. Proikaki, and S. Roumeliotis. 2015. Social capital levels in Greece in times of crisis. In Austerity and the third sector: Civil society at the European frontline, ed. J. Clarke, A. Huliaras, and D.A. Sotiropoulos. London: Routledge.

Kalogeraki, S. 2018. Experiences of the economic crisis: Volunteering in social solidarity networks during the recession in Greece. In Citizens and the crisis: Experiences, perceptions, and responses to the Great Recession in Europe, ed. M. Giugni and M.T. Grasso, 165. London: Palgrave.

Kaufmann, F.-X. 2013. In Variations of the welfare state: Great Britain, Sweden, France and Germany between capitalism and socialism, ed. F.-X. Kaufmann (Hrsg.), 23-239. Berlin: Springer (translated from German by Thomas Dunlap).

Klüver, H. 2011. The contextual nature of lobbying: Explaining lobbying success in the European Union. European Union Politics 12 (4): 483-506.

Kousis, M. 1999. Sustaining local environmental mobilisations: Groups, actions and frames in southern Europe. Environmental Politics 8 (1): 172-198.

Kousis, M., D. Della Porta, and M. Jiménez. 2008. Southern European environmental movements in comparative perspective. American Behavioral Scientist, Special issue Mediterranean Political Processes in Historical-Comparative Perspective, Guest eds. C. Tilly, R. Franzosi and M. Kousis 51(11):1627-1647.

Kousis, M., S. Kalogeraki, and M. Mexi. 2015. Alternative forms of resilience and policy change: An exploration of the theoretical, empirical and policy dimensions. In LIVEWHAT scientific conference, University of Geneva, October 14-16.

Kousis, M., and M. Paschou. 2017. Alternative forms of resilience: A typology of approaches for the study of citizen collective responses in hard economic times, in special section Alternative Forms of Resilience Confronting Hard Economic Times. A South European Perspective. PArtecipazione e COnflitto 10(1):136-168. https://siba-ese.unisalento.it/index.php/paco/article/view/17119.

Kriesi, H. 2007. Organizational resources: Personnel and finances. In Social capital and associations in European democracies, eds. W.A. Maloney, and S. Rossteutscher, 136-170. Routledge.

Kröger, S., 2017. Strategic or principled? The engagement of civil society organizations with the EU. Journal of Civil Society 14 (1): 41-57. 
Lahusen, C., M. Kousis, U. Zschache, and A. Loukakis. 2018. European solidarity in times of crisis: Comparing transnational activism of civic organisations in Germany and Greece. Österreichische Zeitschrift für Soziologie Special Issue 18(or 19): Power and Counter Power in the Transnational Restructuring of Social Spaces and Social Fields in Europe 43:173-196.

Longest, K.C., and S. Vaisey. 2018. Fuzzy: A program for performing qualitative comparative analyses (QCA) in stata. The Stata Journal: Promoting Communications on Statistics and Stata 8 (1): 79-104.

Loukakis, A. (2016, September). Something more than offering help! Exploring the links between solidarity and social movement initiatives in Greece in times of economic crisis. In Paper presented at the 10th European Consortium for Political Research General Conference, Charles University in Prague.

Maloney, W.A., and S. Rossteutscher (eds.). 2007. Social capital and associations in European democracies: A comparative analysis. London: Routledge.

Mello, P.A. 2012. Parliamentary peace or partisan politics? Democracies' participation in the Iraq War. Journal of International Relations and Development 15 (3): 420-453.

Papadaki, M., and S. Kalogeraki. 2017. Social support actions as forms of building community resilience at the onset of the crisis in urban Greece: The case of Chania, in special section Alternative Forms of Resilience Confronting Hard Economic Times. A South European Perspective. PArtecipazione e COnflitto 10(1):193-220.

Pennings, P. 2009. Fuzzy-sets and QCA-The methodology of the fuzzy-set logic and its application. In Methoden der vergleichenden Politik-und Sozialwissenschaft, 347-363. Wiesbaden: VS Verlag für Sozialwissenschaften.

Petmesidou, M. 1996. Social protection in Greece: A brief glimpse of a welfare state. Social Policy and Administration 30 (4): 324-347.

Petmesidou, M., and A. Guillén. 2014. Can the welfare state as we know it survive? A view from the crisis-ridden south European periphery. South European Society and Politics 19 (3): 295-307. https ://doi.org/10.1080/13608746.2014.950369.

Ragin, C.C. 1987. The comparative method. Moving beyond qualitative and quantitative strategies. Berkeley, Los Angeles and London: University of California Press.

Ragin, C.C. 2000. Fuzzy-set social science. Chicago: University of Chicago Press.

Ragin, C.C. 2008. Redesigning social inquiry: Fuzzy sets and beyond, vol. 240. Chicago: University of Chicago Press.

Ragin, C.C. 2009. In Qualitative comparative analysis using fuzzy sets (fsQCA), B. Rihoux, ed.

Rohlfing, I. 2012. Analyzing multilevel data with QCA: A straightforward procedure. International Journal of Social Research Methodology 15 (6): 497-506.

Schneider, C.Q., and C. Wagemann. 2006. Reducing complexity in Qualitative Comparative Analysis (QCA): Remote and proximate factors and the consolidation of democracy. European Journal of Political Research 45 (5): 751-786.

Schneider, C.Q., and C. Wagemann. 2009. Standards guter praxis in qualitative comparative analysis (QCA) und fuzzy-sets. In Methoden der vergleichenden Politik- und Sozialwissenschaft, Susanne Pickel, Gert Pickel, Hans-Joachim Lauth, Detlef Jahn, eds, 317-412. Neue Entwicklungen und Anwendungen.

Schneider, C.Q., and C. Wagemann. 2012. Set-theoretic methods for the social sciences: A guide to qualitative comparative analysis. Cambridge: Cambridge University Press.

Simiti, M. 2017. Civil society and the economy: Greek civil society during the Economic Crisis. Journal of Civil Society 13 (4): 357-373.

Skleparis, D. 2015. Towards a hybrid 'Shadow State'? The case of migrant-/refugee-serving NGOs in Greece. In Austerity and the third sector: Civil society at the European frontline, ed. J. Clarke, A. Huliaras, and D.A. Sotiropoulos. London: Routledge.

Snow, D.A., S.A. Soule, and H. Kriesi (eds.). 2008. The Blackwell companion to social movements. Hoboken: Wiley.

Sotiropoulos, D. 2014. Civil society in Greece in the wake of the economic crisis. Athens: Konrad Adenauer Stiftung.

Sotiropoulos, D.A., and D. Bourikos. 2014. Economic crisis, social solidarity and the voluntary sector in Greece. Journal of Power, Politics and Governance 2 (2): 33-53.

Sotiropoulos, D., and E. Karamagioli. 2006. Greek civil society: The long road to maturity. Athens: Civicus Civil Society Index Shortened Assessment Tool Report for the Case of Greece

Stjerno, S. 2011. The idea of solidarity in Europe. European Journal of Social Law 3: 156-176. 
Tranow, U. 2012. Das Konzept der Solidarität: Handlungstheoretische Fundierung eines soziologischen Schlüsselbegriffs. Wiesbaden: Springer.

Tzifakis, N., S. Petropoulos, and A. Huliaras. 2017. The impact of economic crises on NGOs: The case of Greece. VOLUNTAS: International Journal of Voluntary and Nonprofit Organization 28 (5): 2176-2199.

Van Oorschot, W. 2008. Solidarity towards immigrants in European welfare states. International Journal of Social Welfare 17 (1): 3-14.

Vathakou, E. 2015. Citizens' solidarity initiatives in Greece during the financial crisis. In Austerity and the third sector in Greece: Civil society at the European frontline, ed. J. Clarke, A. Huliaras, and D.A. Sotiropoulos, 167-189. London: Routledge.

Von Bülow, M. 2010. Building transnational networks_Civil society networks and the politics of trade in the Americas. Cambridge: Cambridge University Press.

Zimmer, A., A. Appel, C. Dittrich, B. Sittermann, and F. Stallmann. 2009. Germany: On the social policy centrality of the free welfare associations. In Handbook on third sector policy in Europe: multi-level processes and organized civil society, ed. J. Kendall, 21-42. Cheltenham: Edward Elgar.

Zmerli, S., and K. Newton. 2007. Networking among voluntary associations: Segmented or integrated? In Social capital and associations in European democracies, ed. Maloney, W.A., and S. Rossteutscher, 171-192. Routledge.

Publisher's Note Springer Nature remains neutral with regard to jurisdictional claims in published maps and institutional affiliations.

\section{Affiliations}

\section{Lía Durán Mogollón ${ }^{1} \cdot$ Olga Eisele $^{2} \cdot$ Maria Paschou $^{3}$}

\section{Olga Eisele}

olga.eisele@univie.ac.at

Lía Durán Mogollón

duran-mogollon@soziologie.uni-siegen.de

Maria Paschou

mpashou7@hotmail.com

1 Department of Sociology, University of Siegen, Siegen, Germany

2 Department of Communication, University of Vienna, Vienna, Austria

3 Department of Sociology, University of Crete, Rethymno, Greece 